\title{
Injectable Versus Oral First-Line Disease-Modifying Therapies: Results from the Italian MS Register
}

\author{
Emanuele D'Amico ${ }^{1}$ (D) - Aurora Zanghì ${ }^{1}$. Marzia Romeo ${ }^{2}$ - Eleonora Cocco ${ }^{3}$. Giorgia Teresa Maniscalco ${ }^{4}$. \\ Vincenzo Brescia Morra ${ }^{5}$. Damiano Paolicelli ${ }^{6}$. Giovanna De Luca ${ }^{7}$. Simonetta Galgani ${ }^{8}$. Maria Pia Amato ${ }^{9,10}$. \\ Giuseppe Salemi ${ }^{11}$. Matilde Inglese ${ }^{12,13}$. Paolo Agostino Confalonieri ${ }^{14}$. Giacomo Lus ${ }^{15} \cdot$ Carlo Avolio $^{16}$. \\ Antonio Gallo ${ }^{17} \cdot$ Marika Vianello $^{18} \cdot$ Marco Onofrj $^{7} \cdot$ Massimo Filippi ${ }^{19,20} \cdot$ Maria Trojano $^{6} \cdot$ Francesco Patti $^{1}$
}

Accepted: 21 December 2020 / Published online: 2 February 2021

(C) The Author(s) 2021

\begin{abstract}
The current study aims to compare injectable and oral first-line disease-modifying therapies (DMTs) for time to first relapse, time to confirmed disability progression (CDP), and time to discontinuation using a cohort of relapsing remitting multiple sclerosis (RRMS) patients, with data extracted from the Italian MS Register. This multicenter, observational, retrospectively acquired, and propensityadjusted cohort study utilized RRMS-naïve patients from the Italian MS Register who started either injectable or oral first-line DMTs between January 1, 2010, and December 31, 2017, to evaluate the impact on disability outcomes in patients. Enrolled patients were divided into two groups, namely the injectable group (IG) and the oral group (OG). Of a cohort of 11,416 patients, 4602 were enrolled (3919 in the IG and 683 in the OG). The IG had a higher rate of women $(67.3 \%$ vs $63.4 \%, p<0.05)$ and a lower mean age $(36.1 \pm 10.9$ vs $38.9 \pm 11.8, p<0.001)$. The event time to first relapse demonstrated a lower risk in the $\mathrm{OG}(\mathrm{HR}=0.58 ; \mathrm{CI}$ $95 \% 0.48-0.72, p<0.001)$. However, no differences were found between the two groups with respect to the risk of CDP $(\mathrm{HR}=$ 0.94; CI 95\% 0.76-1.29, $p=0.941)$, while a lower risk of DMT was found in the OG (HR $=0.72$; CI 95\% 0.58-0.88, $p=0.002)$ for the event time to discontinuation. Real-world data from the Italian MS Register suggests that first-line oral DMTs are associated with a lower risk of experiencing a new relapse and of therapy discontinuation compared to injectable DMTs.
\end{abstract}

Emanuele D'Amico

emanuele.damico@unict.it

1 Department "G.F. Ingrassia", MS center, University of Catania, Policlinico G. Rodolico, V. Santa Sofia 78, 95123 Catania, Italy

2 Neurorehabilitation Unit, IRCCS San Raffaele Scientific Institute, Milan, Italy

3 Department "Medical Science and Public Health", University of Cagliari, Cagliari, Italy

4 Multiple Sclerosis Center and Neurological Clinic Stroke Unit , “A. Cardarelli” Hospital, Naples, Italy

5 Multiple Sclerosis Center, University of Naples "Federico II", Naples, Italy

6 Department of Basic Medical Sciences, Neuroscience and Sense Organs, University of Bari “Aldo Moro", Policlinico, Bari, Italy

7 Neurology Unit, University G. D’Annunzio, Policlinico SS Annunziata, Chieti, Italy

8 Multiple Sclerosis Center - Az. Osp. S. Camillo Forlanini, Rome, Italy

9 Department NEUROFARBA University of Florence, Florence, Italy

10 IRCCS Fondazione Don Carlo Gnocchi, Florence, Italy
11 Department of Biomedicine, Neurosciences and Advanced Diagnostics, University of Palermo, Palermo, Italy

12 Dipartimento Di Neuroscienze, Riabilitazione, Oftalmologia, Genetica E Scienze Materno - Infantili, Clinica Neurologica (DiNOGMI), Genoa, Italy

13 Ospedale Policlinico San Martino, IRCCS, Genoa, Italy

14 Fondazione IRCCS Istituto Neurologico Carlo Besta, Milan, Italy

15 MS Center, II Division of Neurology, University della Campania “L. Vanvitelli”, Naples, Italy

16 Centro Interdipartimentale Malattie Demielinizzanti, AOU Ospedali Riuniti Di Foggia, Foggia, Italy

17 MS Center, I Division of Neurology, University della Campania "L. Vanvitelli", Naples, Italy

18 O.U. Neurology “Ca' Foncello” Hospital - Treviso - MS Unit, Treviso, Italy

19 Neurology Unit, Neurorehabilitation Unit, Neurophysiology Service, and Neuroimaging Research Unit, Division of Neuroscience, IRCCS San Raffaele Scientific Institute, Milan, Italy

20 Vita-Salute San Raffaele University, Milan, Italy 
Key Words Multiple sclerosis $\cdot$ injectable DMTs $\cdot$ oral DMTs $\cdot$ real-world setting $\cdot$ EDSS score

\section{Introduction}

Multiple sclerosis (MS) therapies have changed considerably over the last several decades, with the approval of oral diseasemodifying therapies (DMTs) following the demonstration of efficacy and safety for the treatment of the relapsing forms of MS (RRMS) [1].

Prior to 2010, only DMTs administered by injection were available as an initial therapeutic option. Later, two oral drugs were approved in European countries as first-line DMTs: delayed release dimethyl fumarate (DMF), also known as gastroresistant DMF, and teriflunomide (TRF) [2, 3]. Pivotal trials demonstrated the benefits of both DMF and TRF with clinical (i.e., number of clinical relapses and disability accrual) and magnetic resonance imaging (MRI) disease activity, with a generally good safety profile [4-11]. Real-world evidence (RWE) studies have shown that treatment with DMF and TRF controlled similar disease activity (assessed by no evidence of disease activity, NEDA-3, and time to the new first clinical relapse at a 12month follow-up) and that the two DMTs showed comparable discontinuation rates at a 24-month follow-up [12, 13].

Established efficacy evidence for reducing relapsing activity and disability progression is available for all licensed firstline DMTs, but the need for real data of comparison between the established and the newer first-line DMTs in unselected patient populations is still needed to define treatment sequences and to gather real-world data on long-term outcomes [8-11, 14-19].

In the last several years, the Italian MS Register, the largest national clinical database with about 140 Italian MS centers, offered the opportunity to study real-world clinical outcomes in large cohorts of patients to represent daily clinical practice $[18,20]$.

The aim of the current study was to evaluate long-term outcomes of first-line DMTs in terms of time to first relapse, time to confirmed disability progression (CDP), and, additionally, time to discontinuation in RRMS-naïve patients by focusing on the direct comparison between injectable and oral first-line DMTs, namely interferons and glatiramer acetate compared to dimethyl fumarate and teriflunomide [18].

\section{Methods}

\section{Population}

A multicenter, observational, retrospectively acquired cohort study was utilized for the current study. Anonymized clinical data of patients with RRMS were extracted from the Italian MS Register from their first treatment prescription with injectable and oral DMTs (between January 1, 2010 and December 31, 2017) to their last follow-up with the same treatment [20].

Key eligibility criteria included (1) a diagnosis of RRMS according to the $2010 \mathrm{McDonald}$ criteria [21]; (2) aged between 18 to 55 years at the time of first DMT prescription; (3) start of injectable or oral first-line DMTs between January 1, 2010, and December 31, 2017; (4) continuous exposure to the investigated DMTs for $\geq 6$ months; and (5) patients with at least three visits (including baseline) with an Expanded Disability Status Scale evaluation (EDSS).

RRMS-naïve patients who matched the required criteria were divided into two groups for the analyses, the injectable group (IG) and oral group (OG). The IG included RRMS patients who were treated with either Copaxone ( $40 \mathrm{mg}$ per $\mathrm{ml} /$ three times per week subcutaneously and at least $48 \mathrm{~h}$ apart) or IFNs (interferon $\beta$ - $1 \mathrm{a}$ and interferon $\beta-1 \mathrm{~b}, 30 \mu \mathrm{g} / 0.5 \mathrm{~mL}$, once weekly, intramuscularly or interferon $\beta$-1a, either $22 \mathrm{mcg}$ or 44 $\mathrm{mcg}$, three times per week subcutaneously) [22-25]. The OG included RRMS patients who were treated with either DMF (120 mg twice per day for the first 7 days, then $240 \mathrm{mg}$ twice per day) or TRF (14 mg once per day) [2, 3].

\section{Study Endpoints}

The primary study outcome was the evaluation of time to first relapse and time to CDP. The time interval from baseline to the first event (for patients with an event) or to the last evaluation at follow-up (for patients without an event) was examined. Additionally, the time to discontinuation of the first prescribed DMT was evaluated.

\section{Procedures and Outcomes}

Patients were included in the study at the initiation of treatment (baseline) and were monitored over their full time on the medication with data collection performed at baseline and approximately every 6 months during the time of exposure. Patients were censored at treatment discontinuation or at their last recorded clinical visit.

A relapse was defined as new symptoms or an exacerbation of existing symptoms persisting for $\geq 24 \mathrm{~h}$ in the absence of concurrent illness/fever and occurring $\geq 30$ days after a previous relapse. CDP events were defined as $\geq 6$-month confirmed increases of either $\geq 0.5$ points for patients with a baseline EDSS score $>5.5, \geq 1.0$ point for those with a baseline EDSS score of 1 and 5.5, and $\geq 1.5$ points for those with a baseline EDSS score of 0. A minimum of three visits, including the baseline visit, with an EDSS score evaluation, was required. EDSS scores recorded within 30 days after the onset of a relapse were excluded. 
Discontinuation of investigated drugs was defined as a gap of treatment for 60 or more days. Time to discontinuation (in months) was measured as the time between the index date and the end of the supply of the prescriptions dispensed.

\section{Statistical Analyses}

Data are presented as counts (proportions) for categorical variables and mean (standard deviation, SD) or median (interquartile range, IQR) for continuous variables. Unpaired $t$ tests and Mann Whitney tests were used to compare continuous variables according to their distribution. Chi-square tests were used to compare categorical variables. Univariate nonparametric Kaplan Meier (K-M) curves and log-rank tests were used to evaluate the events under investigation in the entire sample.

A Schoenfeld's global test was used to verify the proportional hazards assumption for the time-on-treatments. Once the proportionality assumption was verified, a Cox proportional model was built for each investigated outcome in the entire sample. A Cox proportional hazard univariate regression model was used to estimate the hazard ratio (HR) and its 95\% confidence interval (CI).

To take into account the imbalance of the two groups, a propensity score (PS) was calculated.

Additionally, a logistic regression was conducted to evaluate all patients using treatment (injectable vs oral) as the independent variable and baseline levels of sex, age, type of MS onset (monofocal or multifocal), EDSS score, number of relapses in the year prior to onset, and disease duration as covariates. Inverse probability of treatment weight (IPTW) and the stabilized inverse probability of treatment weight (SIPTW) were also calculated.

Standardized differences calculated in weighted (using the stabilized weights) and unweighted samples were used to assess the balance of baseline covariates between treated and control.

Multivariable Cox proportional hazard regression models weighted for IPTW were performed to evaluate the relationship between outcomes and treatment groups. HRs and 95\% CIs were calculated to evaluate the relationship between outcomes and the treatment group.

For the analysis of relapse outcomes, a negative binomial model and weighted negative binomial model were conducted, using the annual relapse rate as the dependent variable and group as the independent variable.

To better examine the differences between the two treatment strategies in mild-to-moderate patients, subgroup univariate analyses were conducted, stratifying patients on baseline EDSS scores $(\leq 2$ and $>2)$ and for number of relapses in the pre-baseline year (1 or more than 1 ), and a Cox proportional hazard univariate regression model was applied to each subgroup. HRs and their 95\% CIs were reported. A sensitivity analysis was conducted on patients with at least 30 months of follow-up.

Furthermore, as a method of correcting the variables that were not measured, the E-value proposed by VanderWeele et al. was calculated [26]. The E-value was defined as the minimum strength of association on the hazard ratio scale that an unmeasured confounding variable would need to have with both the group and the outcome to fully explain the specific group-outcome association, conditional on the measured covariates.

Missing data were handled through multiple imputation. The analysis used normalized weights to approximate the inferences in the data with data missing not at random (MNAR) [27]. The associations between missingness of the baseline data and other demographical and clinical characteristics were calculated with a multivariate logistic regression analysis, as previously published $[28,29]$.

All results were considered significant at 0.05 . Stata 16.1 was used for all analyses.

\section{Protocol Approvals Standard, Registrations, and Patient Consents}

Use of the Italian MS Register was approved by the Ethics Committee of the University of Bari (Italy) as the coordinator center (Reference numbers 0055587 and 0052885 ) and by the local Ethics Committees of all participant centers. The study protocol for the current analysis was also discussed and approved by the Scientific Committee of the Italian MS Register. Each subject enrolled with a diagnosis of MS was required to sign written informed consent to enter the Register. In some centers in which data had been collected before the Register was set up, depending on local laws and regulations, historical data collected retrospectively were also included without informed consent when the patient was not traceable due to death, transfer, or for other reasons. The current report does not contain any individual or identifying information.

\section{Data Availability}

Anonymized data will be shared by request from a qualified investigator for the sole purpose of replicating procedures and results presented in the report, provided that the data transfer is in agreement with EU legislation on the general data protection regulation.

\section{Results}

\section{Participants}

Out of a cohort of 37,012 patients selected from the Italian MS Register, 11,416 started their first DMT during the index 
window. Out of those subjects, 4602 (3919 in the IG and 683 in the OG) were considered eligible for the analyses and were subsequently enrolled (Fig. 1).

Baseline characteristics by group are shown in Table 1. Patients in the IG had a higher rate of women $(67.3 \%$ vs $63.4 \%, p<0.05)$ and a lower mean age $(36.1 \pm 10.9$ vs 38.9 $\pm 11.8, p<0.001$, see Table 1).

Median disease duration was longer in the IG (66 months with a range of 23-249 compared to 70 months with a range of $21-277, p<0.0001)$.

The median follow-up of the total cohort was 36 months (IQR $=22-36$ months), while the follow-up in the IG was a median of 36 months (IQR $=28-36$ months) and the OG median was 19 months (IQR $=12-27$ months), $p<0.0001$.

\section{Findings on the Pre-matched Samples}

During the follow-up, 1477 patients relapsed $(n=1363$ (35\%) in the IG, $n=114$ (17\%) in the OG). A log-rank test demonstrated that the risk to experience the first relapse was lower in the OG $(p<0.001$, Fig. 2$)$, which was also confirmed by the Cox model $(\mathrm{HR}=0.57$; CI 95\%: 0.47-0.69).

A negative binomial model and weighted negative binomial model were applied using the annual relapse rate as the dependent variable and group (IG vs. OG) as the independent variable. The incidence rate ratio $(\mathrm{OG}$ vs. IG) was 0.63 (95\% CI: $0.51-0.78, p<0.001)$. After an inverse probability weighting, the incidence rate ratio was 0.65 (95\% CI: $0.52-0.82, p<0.001)$. Taking this into consideration with the total count of relapses, the OG demonstrated a lower risk than the IG.

The event CDP was observed in 641 patients $(n=$ $574(15 \%)$ in the IG, $n=67(10 \%)$ in the OG). The risk to reach CDP did not differ between the two groups using a log-rank test $(p=0.370$, Fig. 3$)$. This was confirmed by the Cox model $(\mathrm{HR}=1.12 ; 95 \% \mathrm{CI}$ : $0.87-1.45, p=0.370$ ).

Finally, DMT discontinuation was observed in 1456 patients $(n=1352(34.5 \%)$ in the IG, $n=104(15 \%)$ in the $\mathrm{OG})$. The risk of DMT discontinuation was lower in the OG as per the log-rank test $(p<0.001)$, which was confirmed by the Cox model (HR $=0.71 ; 95 \%$ CI: $0.58-0.86$, Fig. 4 ).

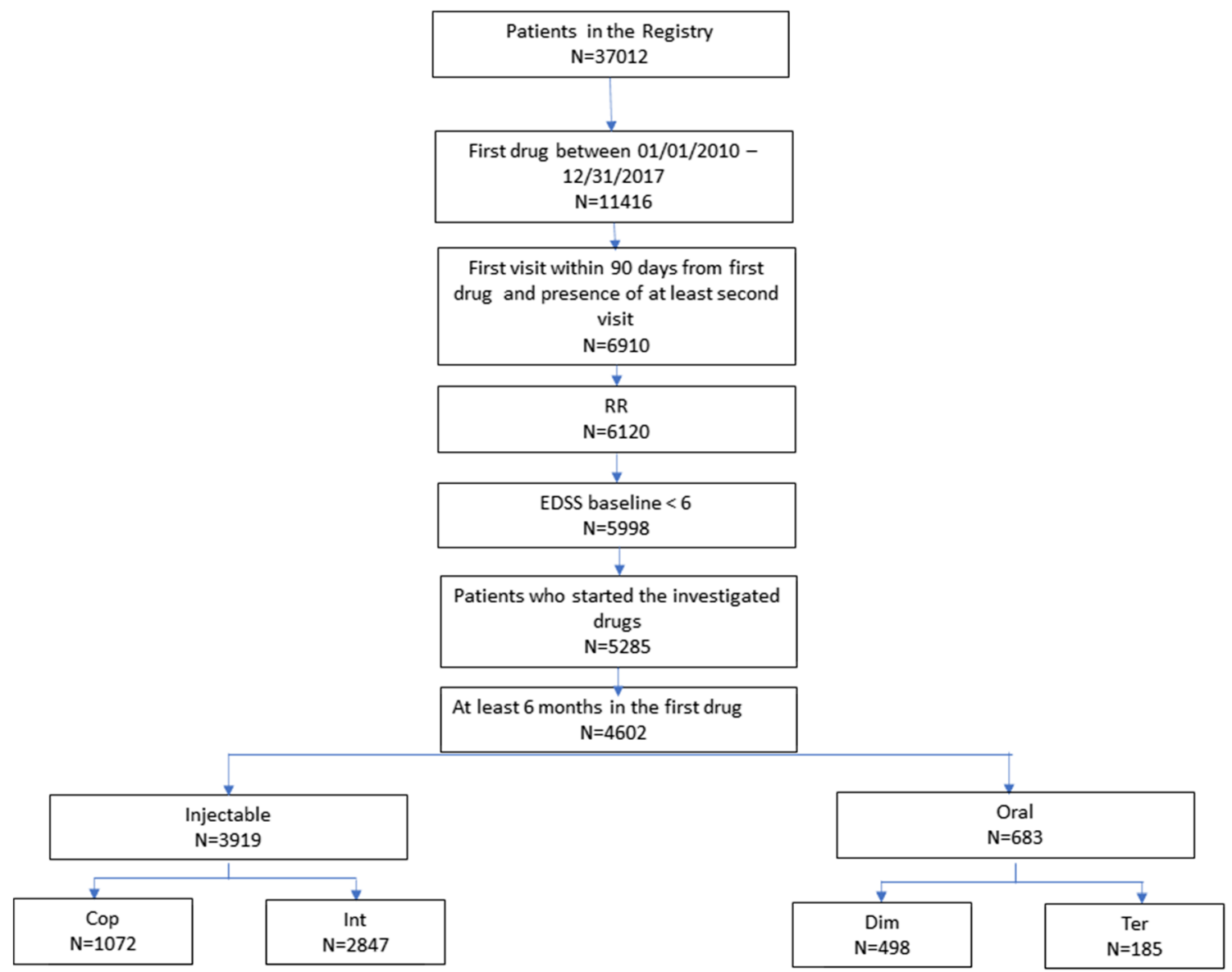

Fig. 1 Patients' selection flow chart. DMT, disease-modifying therapies; EDSS, Expanded Disability Status Scale; IG, injectable group; OG, oral group; RRMS, relapsing remitting multiple sclerosis 
Table 1 Baseline characteristics of the two groups

\begin{tabular}{|c|c|c|c|c|c|c|c|}
\hline \multirow[b]{2}{*}{$N$} & \multicolumn{2}{|l|}{ IG } & \multicolumn{2}{|l|}{ OG } & \multirow[b]{2}{*}{$p$} & \multirow{2}{*}{$\begin{array}{l}\text { Unweighted standardized } \\
\text { mean differences }\end{array}$} & \multirow{2}{*}{$\begin{array}{l}\text { Weighted standardized } \\
\text { mean differences }\end{array}$} \\
\hline & 3919 & & 683 & & & & \\
\hline Female $(n, \%)$ & 2639 & 67.3 & 433 & 63.4 & 0.044 & 0.08 & -0.01 \\
\hline Age (mean, sd) (year) & 36.1 & 10.9 & 38.9 & 11. & $<0.001$ & -0.25 & 0.01 \\
\hline Monofocal onset $(n, \%)$ & 3750 & 95.7 & 649 & 95 & 0.434 & 0.03 & -0.0003 \\
\hline EDSS at baseline (median, q1-q3) & 1.5 & $1-2$ & 1.5 & $1-2.5$ & 0.245 & -0.07 & 0.01 \\
\hline Relapses in the year before treatment start $(n, \%)$ & 2763 & 70.5 & 462 & 67.6 & 0.132 & 0.06 & 0.02 \\
\hline ARR (mean, sd)* & 1.4 & 0.6 & 1.3 & 0.7 & 0.388 & 0.04 & 0.01 \\
\hline DD (median, q1-q3) & 66 & $23-249$ & 70 & $21-277$ & 0.0001 & -0.12 & 0.01 \\
\hline
\end{tabular}

*Only in patients with relapses in the last year

$A R R$, annualized relapse rate; EDSS, Expanded Disability Status Scale; $I G$, injectable group; $O G$, oral group; $D D$, disease duration

\section{Findings After IPW PS Adjustment}

Results from the Cox models following the IPW PS adjustment were consistent with the previous models (Fig. 5). The event time to first relapse demonstrated a lower risk in the OG $(\mathrm{HR}=0.58$; 95\% CI: $0.48-0.72$, $p<0.001)$. No differences were found for the risk of CDP between the two groups $(\mathrm{HR}=0.94 ; 95 \% \mathrm{CI}$ : $0.76-1.29, p=0.941)$. However, a lower risk of DMT discontinuation was found in the $\mathrm{OG}(\mathrm{HR}=0.72 ; 95 \%$ CI: $0.58-0.88, p=0.002$, Fig. 5).

\section{Subgroup Analyses}

Subgroup analyses were also performed for each investigated outcome to examine any difference in the two groups in mildto-moderate patients. IG and OG subjects were stratified based on their baseline EDSS score $(\leq 2$ or $>2)$ and the number of relapses during the year prior to their baseline visit ( 1 or $>1$, Table 2).

The OG had lower risk of event time to first relapse than the IG, for both EDSS subgroups and the subgroup with one relapse in the year prior to baseline (Table 2). Furthermore, the risk of discontinuation was lower in the OG for subjects with an EDSS $\leq 2$ and for both relapse subgroups (Table 2). There were no statistically significant differences found between the two groups for CDP.

\section{Sensitivity Analysis}

A sensitivity analysis was conducted on 3007 (139 OG and $2868 \mathrm{GI}$ ) subjects with at least 30 months (out of 36) of follow-up. The interquartile range around the median at follow-up visits became much smaller, with
Fig. 2 Time to first relapse between the two groups

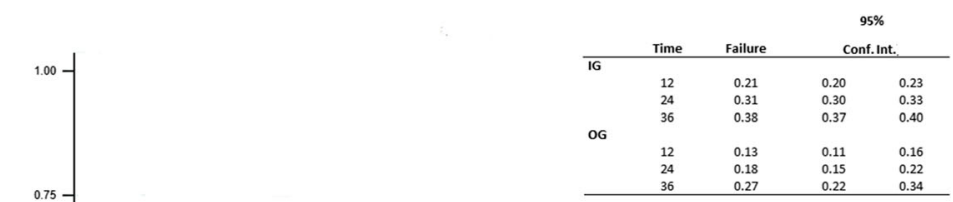

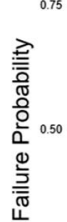

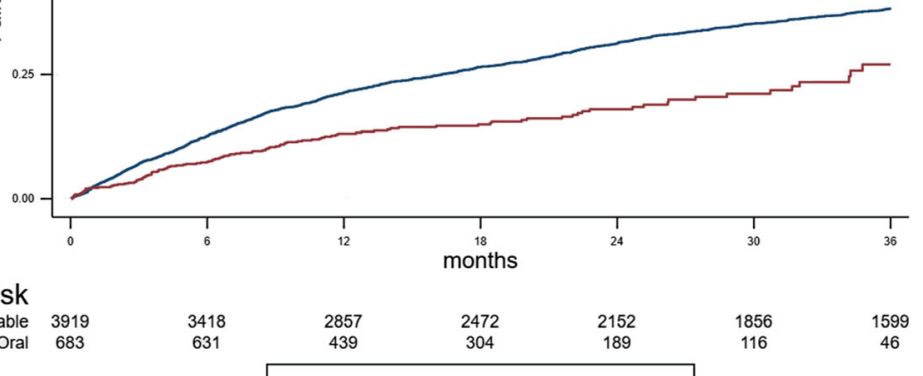


Fig. 3 Time to CDP between the two groups. CDP, confirmed disability progression

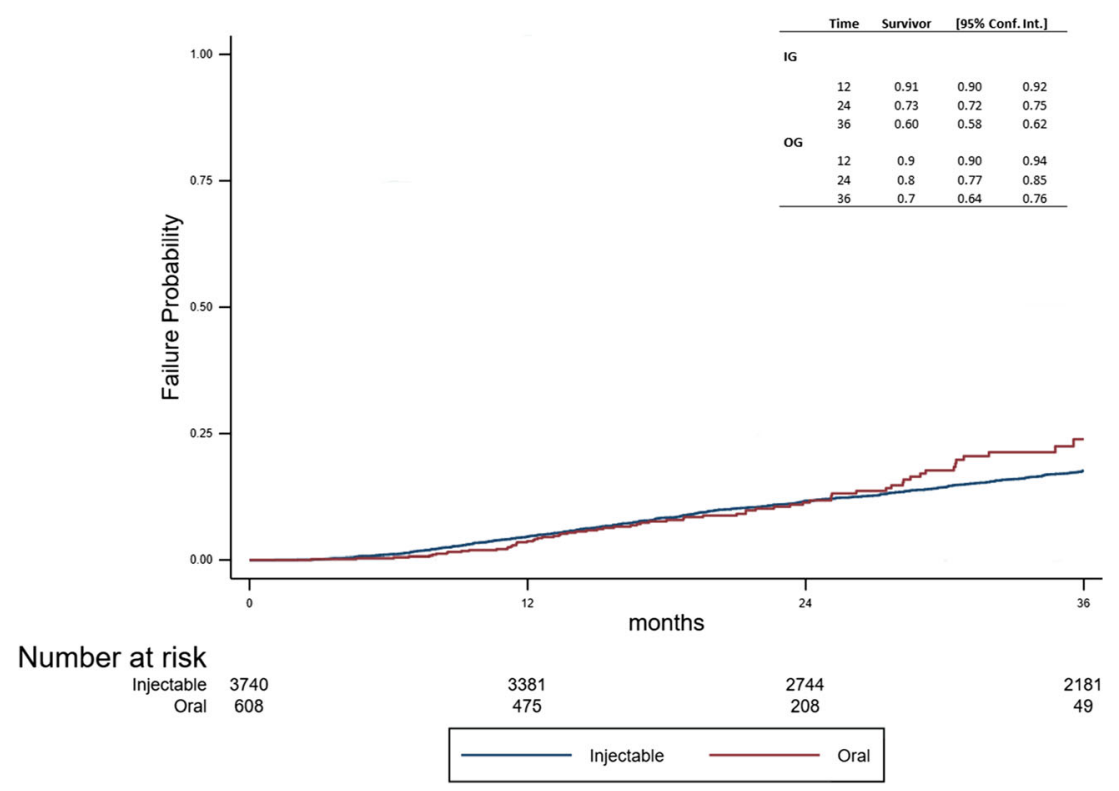

median follow-up of 36 months (IQR $=36-36$ months). In the IG, the median was also 36 months (IQR $=36$ 36 months), while in the OG it was 35 months (IQR = 33-36 months).

Before the PS adjustment, hazard ratios were obtained for first relapse (HR $=0.48 ; 95 \%$ CI: $0.34-0.70, p<0.001)$, for time to CDP (HR $=1.11 ; 95 \%$ CI: $0.74-1.68, p=0.613$ ), and for time to first DMT discontinuation (HR $=0.61 ; 95 \% \mathrm{CI}$ : $0.43-0.87, p=0.006$ ). After IPW PS adjustment, hazard ratios were also obtained for time to first relapse ( $\mathrm{HR}=0.50 ; 95 \%$ CI: $0.35-0.73, p<0.001)$, for time to CDP (HR $=1.12$; 95\% CI: $0.74-1.69, p=0.604)$, and for time to first DMT discontinuation $(\mathrm{HR}=0.62$; 95\% CI: $0.44-0.89, p=0.009)$.

\section{E-Values for Unmeasured Variables}

The observed HRs could be explained away by an unmeasured confounding variable that was associated with in the observed group and the outcome by a E-value of 2.27 for time to relapse, 1.26 for CDP, and 1.82 for DMT discontinuation, but a weak confounding variable could not do this.

\section{Discussion}

In this multicenter, observational, retrospectively acquired cohort study, starting oral first-line DMTs (DMF and TRF) was associated with a lower risk of first relapse occurrence and treatment discontinuation rate during the follow-up, in comparison to first-line injectable DMTs, but no significant difference was found in reaching CDP.

In clinical practice, oral DMTs are gradually replacing the injectable DMTs after they were licensed for RRMS treatment because of their improved tolerability by the patients [30].
However, injectable DMTs have been thoroughly investigated in terms of efficacy and are still largely prescribed for their wellcharacterized safety profile. Moreover, they are still widely considered for patients who intend to become pregnant, having been approved for use during childbearing and breastfeeding (which was recently extended for IFNs) [31,32].

First-line injectable and oral DMTs have not been compared in non-inferiority trials, nor have they been compared in registry based cohorts studies as first choice DMTs [33, 34].

Considering that big data registries offer the opportunity to study real-world clinical outcomes in large cohorts of patients, the strengths of the current work include the generalizability, the representation of daily clinical MS practice, and the large cohort of patients collected in the Italian MS Register, which is the largest national clinical database with about 140 Italian MS centers connected [20,35].

The current data suggest that first-line oral DMTs should be a suitable first choice in RRMS patients when, according to a prognostic profile, a first-line DMT is required.

Patient and disease heterogeneity at the initial presentation and during the disease course makes the increasing treatment choices for RRMS valuable, thereby allowing for the personalization of treatment. First, long-term results of the drug safety and efficacy of a compound may inform decision-making. Here, real-world data and well-structured registries are of importance, as is the statistical method employed. PS adjustment allowed for the mitigation of the effect of heterogeneity of the data. However, all PS methods cannot eliminate bias due to unknown or unmeasured confounding variables. Since an observational retrospective study has biases related to data collection, in particular, in the two groups demonstrating a difference in the follow-up period, the survival analysis allows this to remain under control. Moreover, the sensitivity analysis conducted was limited to patients with at least 30 months of 
Fig. 4 Time to first DMT discontinuation between the two groups

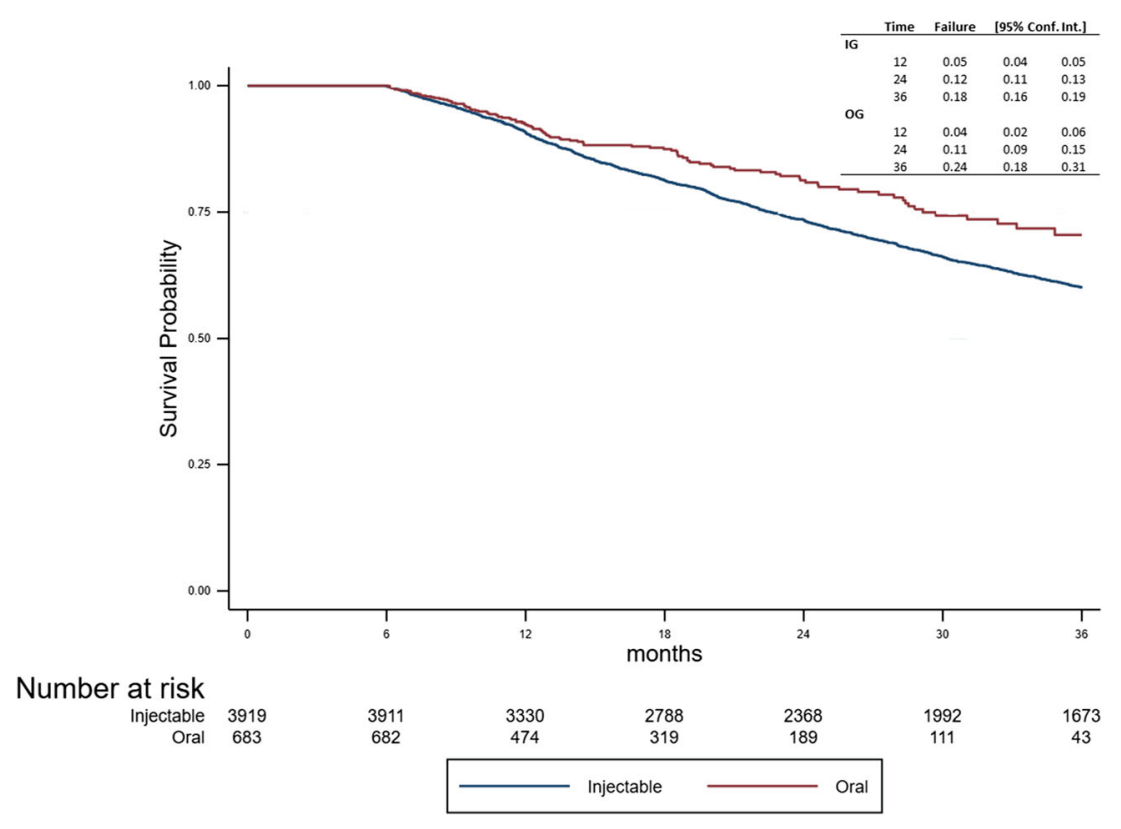

follow-up. The possible effect of unmeasured confounding variables was calculated using an E-value [36-39].

The primary limitations of our study pertain to the observational nature of the data. In addition, MRI activity was not evaluated, nor was there a correction for MRI parameters in the PS model. This may be a limitation, as the current criteria for defining the efficacy of a treatment of MS use composite scores, as no evidence of disease activity (NEDA3) must take into account the presence of new or active (enhancing) lesions on MRI scans [40]. This is, indeed, missing in many realworld studies. The level of evidence of a descriptive study without MRI data is limited and cannot replace a noninferiority trial.

The current study was not designed to compare the safety of the two approaches because the safety data were not sufficiently complete to enable such an analysis. Further research is needed to more accurately identify patients who are most likely to benefit from these therapies.

Supplementary Information The online version contains supplementary material available at https://doi.org/10.1007/s13311-020-01001-6.

Required Author Forms Disclosure forms provided by the authors are available with the online version of this article.

Funding Open Access funding provided by Università degli Studi di Catania.

\section{Compliance with Ethical Standards}

Conflict of Interest This study was not sponsored.

Emanuele D'Amico has nothing to disclose related to this manuscript. Aurora Zanghì has nothing to disclose related to this manuscript.
Marzia Romeo has nothing to disclose related to this manuscript.

Eleonora Cocco has nothing to disclose related to this manuscript.

Giorgia Teresa Maniscalco has nothing to disclose related to this manuscript.

Vincenzo Bresciamorra has nothing to disclose related to this manuscript.

Damiano Paolicelli has nothing to disclose related to this manuscript. Giovanna De Luca has nothing to disclose related to this manuscript. Simonetta Galgani has nothing to disclose related to this manuscript. Maria Pia Amato has nothing to disclose related to this manuscript. Giuseppe Salemi has nothing to disclose related to this manuscript. Matilde Inglese has nothing to disclose related to this manuscript.

Paolo Agostino Confalonieri has nothing to disclose related to this manuscript.

Giacomo Lus has nothing to disclose related to this manuscript.

Carlo Avolio has nothing to disclose related to this manuscript.

Antonio Gallo has nothing to disclose related to this manuscript. Marika Vianello has nothing to disclose related to this manuscript.

Marco Onofrj has nothing to disclose related to this manuscript.

Massimo Filippi has nothing to disclose related to this manuscript.

Maria Trojano has nothing to disclose related to this manuscript.

Francesco Patti served on the advisory board for Bayer, Biogen Celgene, Merck, Novartis, Roche, Sanofi, Teva, and Almirall. He also received personal fees for speaking activities at congresses or sponsored symposia.

Protection of Human Subjects Research References The Italian MS Register was approved by the Ethics Committee of the University of Bari (Italy) as coordinator center (Reference numbers 0055587 and 0052885), and by the local Ethics Committees of all participant centers. The study protocol for this analysis was also discussed and approved by the Scientific Committee of the Italian MS Register. Each person with MS enrolled with a diagnosis of MS is required to sign written informed consent to enter the Register. In some centers where data had been collected before the Register was set up, depending on local laws and regulations, historical data collected retrospectively were also included without informed consent when the patient was not traceable due to death, transfer, or for other reasons. This report does not contain any individual person's information. 
Fig. 5 Analysis of treatment effects in time to first relapse, time to $\mathrm{CDP}$, and time to DMT discontinuation. (Asterisk) The treatment effects were explored by a propensity score adjustment in quintiles for age, duration of disease from onset, Expanded Disability Status Scale at baseline, relapses in the previous year, sex, and clinical onset. CI, confidence interval; $\mathrm{HR}$, hazard ratio; $\mathrm{CDP}$, confirmed disability progression; DMT, disease-modifying therapies; IG, injectable group; OG, oral group
OG

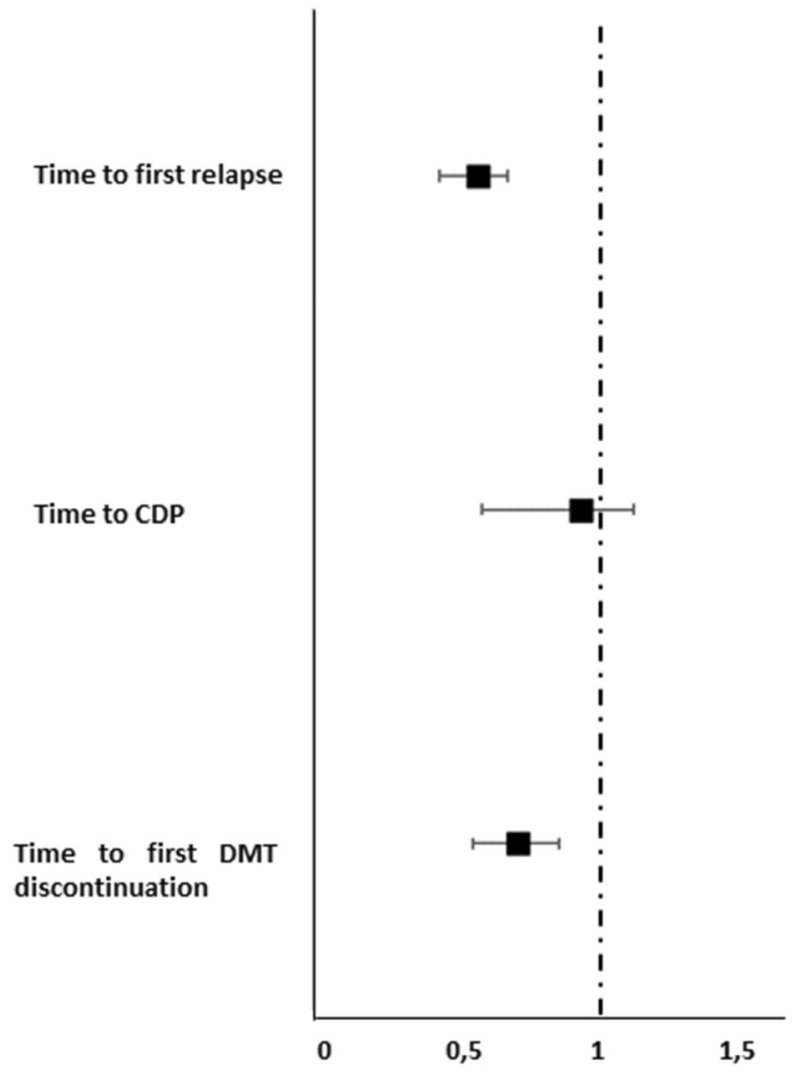

IG

HR

$\mathrm{Cl} * 95 \%$

$0.58 \quad 0.48-0.72$

$0.94 \quad 0.76-1.29$

$0.72 \quad 0.58-0.88$
Table 2 Subgroup univariate analysis of treatment effects in terms of risk of first relapse, CDP, and DMT discontinuation

\begin{tabular}{llllll}
\hline IG vs OG & & & & & \\
\hline & IG & OG & HR & CI 95\% & $p$ \\
\hline First relapse & & & & & \\
EDSS $\leq 2$ & 2971 & 493 & 0.63 & $0.50-0.79$ & $<0.001$ \\
EDSS $>2$ & 948 & 190 & 0.44 & $0.31-0.63$ & $<0.001$ \\
Relapses in the year pre-baseline $(n=1)$ & 3094 & 553 & 0.53 & $0.42-0.67$ & $<0.001$ \\
Relapses in the year pre-baseline $(n>1)$ & 825 & 130 & 0.75 & $0.54-1.06$ & 0.103 \\
CDP & & & & & $0.77-1.46$ \\
EDSS $\leq 2$ & 2836 & 438 & 1.06 & 0.707 \\
EDSS $>2$ & 904 & 170 & 1.22 & $0.79-1.88$ & 0.364 \\
Relapses in the year pre-baseline $(n=1)$ & 2941 & 489 & 1.23 & $0.93-1.63$ & 0.141 \\
Relapses in the year pre-baseline $(n \geq 1)$ & 799 & 119 & 0.76 & $0.40-1.46$ & 0.417 \\
DMT discontinuation & & & & & \\
EDSS $\leq 2$ & 2971 & 493 & 0.64 & $0.50-0.82$ & $<0.001$ \\
EDSS $>2$ & 948 & 190 & 0.85 & $0.61-1.19$ & 0.342 \\
Relapses in the year pre-baseline $(n=1)$ & 3094 & 553 & 0.75 & $0.60-0.94$ & 0.014 \\
Relapses in the year pre-baseline $(n \geq 1)$ & 825 & 130 & 0.58 & $0.37-0.92$ & 0.020 \\
\hline
\end{tabular}

$C D P$, confirmed disability progression; $D M T$, disease-modifying therapies; EDSS, Expanded Disability Status Scale; $I G$, injectable group; $N$, number; $O G$, oral group 


\section{Appendix 1}

Table 3 Authors

\begin{tabular}{|c|c|c|c|}
\hline Name & Location & Role & Contribution \\
\hline $\begin{array}{l}\text { Emanuele } \\
\text { D'Amico }\end{array}$ & Department G.F. Ingrassia, University of Catania, Italy & Author & $\begin{array}{l}\text { Study concept and design, acquisition of data, } \\
\text { supervision }\end{array}$ \\
\hline Aurora Zanghì & Department G.F. Ingrassia, University of Catania, Italy & Author & $\begin{array}{l}\text { Study concept and design, acquisition of data, } \\
\text { supervision }\end{array}$ \\
\hline Marzia Romeo & $\begin{array}{l}\text { Neurology Dept. and INSPE-Institute of Experimental } \\
\text { Neurology, Vita-Salute San Raffaele Univ., Milan }\end{array}$ & Author & Analysis and interpretation of data \\
\hline Eleonora Cocco & $\begin{array}{l}\text { Centro Regionale Per La Diagnosi E La Cura Della } \\
\text { Sclerosi Multipla ASL8 P.O. Binaghi, Cagliari, Italy }\end{array}$ & Author & $\begin{array}{l}\text { Study concept and design, acquisition of data, } \\
\text { supervision }\end{array}$ \\
\hline $\begin{array}{l}\text { Giorgia Teresa } \\
\text { Maniscalco }\end{array}$ & $\begin{array}{l}\text { Regional Center of Diagnosis and Therapy of Multiple } \\
\text { Sclerosis, Naples,Italy }\end{array}$ & Author & $\begin{array}{l}\text { Study concept and design, acquisition of data, } \\
\text { supervision }\end{array}$ \\
\hline $\begin{array}{l}\text { Vincenzo } \\
\text { Bresciamorra }\end{array}$ & AOU Policlinico Federico II, Naples, Italy & Author & $\begin{array}{l}\text { Study concept and design, acquisition of data, } \\
\text { supervision }\end{array}$ \\
\hline Damiano Paolicelli & $\begin{array}{l}\text { Dept. of Basic Medical Sciences, Neuroscience } \\
\text { and Sense Organs, Univ. of Bari “Aldo Moro", } \\
\text { Policlinico, Bari, Italy }\end{array}$ & Author & $\begin{array}{l}\text { Study concept and design, acquisition of data, } \\
\text { supervision }\end{array}$ \\
\hline Giovanna De Luca & $\begin{array}{l}\text { Neurology Unit, Univ. G. D’Annunzio, Policlinico SS } \\
\text { Annunziata Chieti, Italy }\end{array}$ & Author & $\begin{array}{l}\text { Study concept and design, acquisition of data, } \\
\text { supervision }\end{array}$ \\
\hline Simonetta Galgani & $\begin{array}{l}\text { Centro Sclerosi Multipla - Az. Osp. S. Camillo Forlanini, } \\
\text { Roma, Italy }\end{array}$ & Author & $\begin{array}{l}\text { Study concept and design, acquisition of data, } \\
\text { supervision }\end{array}$ \\
\hline Maria Pia Amato & $\begin{array}{l}\text { Dept. NEUROFARBA Univ. of Florence, } \\
\text { MS Center AOU Careggi, Florence, Italy }\end{array}$ & Author & $\begin{array}{l}\text { Study concept and design, acquisition of data, } \\
\text { supervision }\end{array}$ \\
\hline Giuseppe Salemi & $\begin{array}{l}\text { MS centre, Dept of Emergency, Urgency } \\
\text { and Neuroscience, } \\
\text { Univ. of Palermo, Italy }\end{array}$ & Author & $\begin{array}{l}\text { Study concept and design, acquisition of data, } \\
\text { supervision }\end{array}$ \\
\hline Matilde Inglese & $\begin{array}{l}\text { Dipartimento Di Neuroscienze, Riabilitazione, } \\
\text { Oftalmologia, Genetica E Scienze } \\
\text { Materno - Infantili, Clinica } \\
\text { Neurologica - Ospedale Policlinico San } \\
\text { Martino (DiNOGMI), Italy }\end{array}$ & Author & $\begin{array}{l}\text { Study concept and design, acquisition of data, } \\
\text { supervision }\end{array}$ \\
\hline $\begin{array}{l}\text { Paolo Agostino } \\
\text { Confalonieri }\end{array}$ & $\begin{array}{l}\text { Fondazione IRCCS Istituto Neurologico Carlo Besta, } \\
\text { Milan, Italy }\end{array}$ & Author & $\begin{array}{l}\text { Study concept and design, acquisition of data, } \\
\text { supervision }\end{array}$ \\
\hline Giacomo Lus & $\begin{array}{l}\text { MS Center, II Division of Neurology, Univ. della } \\
\text { Campania "L. Vanvitelli", Naples, Italy }\end{array}$ & Author & $\begin{array}{l}\text { Study concept and design, acquisition of data, } \\
\text { supervision }\end{array}$ \\
\hline Carlo Avolio & $\begin{array}{l}\text { Centro Interdipartimentale Malattie } \\
\text { Demielinizzanti - AOU } \\
\text { Ospedali Riuniti Di Foggia }\end{array}$ & co-investigator & Acquisition of data \\
\hline Antonio Gallo & $\begin{array}{l}\text { MS Center, I II Division of Neurology, } \\
\text { Univ. della Campania "L. Vanvitelli", } \\
\text { Naples, Italy }\end{array}$ & Author & $\begin{array}{l}\text { Study concept and design, acquisition of data, } \\
\text { supervision }\end{array}$ \\
\hline Marika Vianello & $\begin{array}{l}\text { Neurology “Ca' Foncello” Hospital - Treviso - MS Unit, } \\
\text { Italy }\end{array}$ & Author & $\begin{array}{l}\text { Study concept and design, acquisition of data, } \\
\text { supervision }\end{array}$ \\
\hline Marco Onofrj & $\begin{array}{l}\text { Neurology Unit, Univ. G. D’Annunzio, Policlinico SS } \\
\text { Annunziata Chieti, Italy }\end{array}$ & Author & $\begin{array}{l}\text { Study concept and design, acquisition of data, } \\
\text { supervision }\end{array}$ \\
\hline Massimo Filippi & $\begin{array}{l}\text { Neuroimaging Research Unit, Institute of Experimental } \\
\text { Neurology, Division of Neuroscience, San Raffaele } \\
\text { Scientific Institute, Vita-Salute San Raffaele University, } \\
\text { Milan, Italy. }\end{array}$ & Author & $\begin{array}{l}\text { Study concept and design, acquisition of data, } \\
\text { supervision }\end{array}$ \\
\hline Maria Trojano & $\begin{array}{l}\text { Dept. of Basic Medical Sciences, Neuroscience } \\
\text { and Sense Organs, Univ. of Bari "Aldo Moro", } \\
\text { Policlinico, Bari, Italy }\end{array}$ & Author & $\begin{array}{l}\text { Study concept and design, acquisition } \\
\text { of data, critical revision of manuscript } \\
\text { for intellectual content }\end{array}$ \\
\hline Francesco Patti & $\begin{array}{l}\text { Department G.F. Ingrassia, University of } \\
\text { Catania, Italy }\end{array}$ & Author & $\begin{array}{l}\text { Study concept and design, } \\
\text { acquisition of data, critical revision of } \\
\text { manuscript for intellectual content }\end{array}$ \\
\hline
\end{tabular}




\section{Appendix 2}

Table 4 Co-investigators for Italian MS register

\begin{tabular}{|c|c|c|c|}
\hline Name & Location & Role & Contribution \\
\hline Francesco Passantino & $\begin{array}{l}\text { Divisione Di Neurologia - Azienda Ospedaliera SS. } \\
\text { Antonio E Biagio E Cesare Arrigo }\end{array}$ & Co-investigator & Acquisition of data \\
\hline Maura Chiara Danni & $\begin{array}{l}\text { Centro SM - Clinica Neurologica - Ospedali Riuniti di } \\
\text { Ancona }\end{array}$ & Co-investigator & Acquisition of data \\
\hline Rocco Totaro & $\begin{array}{l}\text { Centro Malattie Demielinizzanti - Clinica Neurologica, } \\
\text { Ospedale San Salvatore - L'Aquila }\end{array}$ & Co-investigator & Acquisition of data \\
\hline Maria Gabriella Coniglio & Centro Sclerosi Multipla P.O. Madonna delle Grazie & Co-investigator & Acquisition of data \\
\hline Diomira Acquistapace & $\begin{array}{l}\text { Centro Sclerosi Multipla - Azienda Ospedaliera } \\
\text { Regionale S. Carlo }\end{array}$ & Co-investigator & Acquisition of data \\
\hline Roberto Bruno Bossio & U.O. di Neurologia - Centro SM - ASP di Cosenza & Co-investigator & Acquisition of data \\
\hline Paola Valentino & $\begin{array}{l}\text { Centro Sclerosi Multipla - Policlinico } \\
\text { Universitario - Campus Germaneto }\end{array}$ & Co-investigator & Acquisition of data \\
\hline Carlo Pozzilli & S.Andrea MS Center, Sapienza Univ. Rome, Italy & Author & $\begin{array}{l}\text { Study concept and } \\
\text { design, acquisition } \\
\text { of data, supervision }\end{array}$ \\
\hline Sauro Severi & $\begin{array}{l}\text { Ambulatorio SM - Sezione Neurologia - Ospedale } \\
\text { Valdarno, Montevarchi (AR) }\end{array}$ & Co-investigator & Acquisition of data \\
\hline Benedetta Calchetti & $\begin{array}{l}\text { Centro Aziendale SM - U.O. Neurologia - Ospedale S. } \\
\text { Donato, Arezzo }\end{array}$ & Co-investigator & Acquisition of data \\
\hline Daniele Spitaleri & $\begin{array}{l}\text { Centro Sclerosi Multipla - U.O.C. Neurologia, } \\
\text { AORN San G. Moscati di Avellino }\end{array}$ & Co-investigator & Acquisition of data \\
\hline Maurizia Gatto & $\begin{array}{l}\text { Centro Malattie Demielinizzanti - Ospedale Generale } \\
\text { Regionale F. Miulli }\end{array}$ & Co-investigator & Acquisition of data \\
\hline Pietro Iaffaldano & $\begin{array}{l}\text { Centro SM Dipartimento di Scienze Mediche di Base, } \\
\text { Neuroscienze ed. Organi di Senso Universita' di Bari }\end{array}$ & Co-investigator & Acquisition of data \\
\hline Bonaventura Ardito & $\begin{array}{l}\text { Centro Sclerosi Mutipla UOC Di Neurologia - Ospedale } \\
\text { Della Murgia Fabio Perinei }\end{array}$ & Co-investigator & Acquisition of data \\
\hline Valeria Barcella & $\begin{array}{l}\text { Centro Provinciale Sclerosi Multipla, ASST papa } \\
\text { Giovanni XXIII }\end{array}$ & Co-investigator & Acquisition of data \\
\hline Lorenzo Capone & $\begin{array}{l}\text { Centro Clinico delle Malattie Demielinizzanti dell’ASL } \\
\text { di Biella - Ospedale degli Infermi di Biella }\end{array}$ & Co-investigator & Acquisition of data \\
\hline Piero Nicolao & Reparto Di Neurologia, ULSS 1 Dolomiti, Ospedale Di Feltre & Co-investigator & Acquisition of data \\
\hline Alessandra Lugaresi & UOSI Riabilitazione Sclerosi Multipla IRCCS - ISNB & Co-investigator & Acquisition of data \\
\hline Augusto Rini & Centro Sclerosi Multipla - Ospedale A. Perrino & Co-investigator & Acquisition of data \\
\hline Maria Merello & $\begin{array}{l}\text { Azienda Socio Sanitaria Territoriale (A.S.S.T.) } \\
\text { della Franciacorta }\end{array}$ & Co-investigator & Acquisition of data \\
\hline Marta Bianchi & Ospedale Di Esine- Reparto di Neurologia & Co-investigator & Acquisition of data \\
\hline Imma Plasmati & Centro SM c/o U.O. di Neurologia - P.O. Dimiccoli & Co-investigator & Acquisition of data \\
\hline Renato Docimo & Centro Sclerosi Multipla - P.O. San Giuseppe Moscati & Co-investigator & Acquisition of data \\
\hline Giovanna De Luca & $\begin{array}{l}\text { Centro Sclerosi Multipla, Clinica Neurologica Policlinico } \\
\text { SS. Annunziata }\end{array}$ & Co-investigator & Acquisition of data \\
\hline Fiorella Mondino & $\begin{array}{l}\text { Centro Sclerosi Multipla, SC Neurologia, } \\
\text { ASO S.Croce e Carle }\end{array}$ & Co-investigator & Acquisition of data \\
\hline Alessia Di Sapio & Centro SM - Ospedale Regina Montis Regalis & Co-investigator & Acquisition of data \\
\hline Raffaella Clerici & $\begin{array}{l}\text { Centro ad Alta Specializzazione per la diagnosi e la cura } \\
\text { della sclerosi multipla - Ospedale Generale di zona Valduce }\end{array}$ & Co-investigator & Acquisition of data \\
\hline Nerina Mascoli & $\begin{array}{l}\text { Centro SM UO Neurologia ASST Lariana } \\
\text { Ospedale S. Anna Como }\end{array}$ & Co-investigator & Acquisition of data \\
\hline Maria Teresa Ferrò e Paola Grossi & $\begin{array}{l}\text { Neuroimmunologia - Centro Provinciale per la diagnosi e } \\
\text { terapia della Sclerosi Multipla, ASST Crema }\end{array}$ & Co-investigator & Acquisition of data \\
\hline Davide Maimone & Centro Sclerosi Multipla - Osp. Garibaldi - Nesima & Co-investigator & Acquisition of data \\
\hline Silvia Strumia & $\begin{array}{l}\text { Ambulatorio Sclerosi Multipla della U.O. di } \\
\text { Neurologia- sede di Forli'- AUSL della Romagna }\end{array}$ & Co-investigator & Acquisition of data \\
\hline Maura Pugliatti & Centro Di Servizio E Ricerca Sulla Sclerosi Multipla & Co-investigator & Acquisition of data \\
\hline
\end{tabular}


Table 4 (continued)

\begin{tabular}{|c|c|c|c|}
\hline Name & Location & Role & Contribution \\
\hline Daniela Cargnelutti & $\begin{array}{l}\text { SOC Neurologia - Day Hospital, ASUIUD P.O. S.Maria } \\
\text { Della Misericordia - Udine }\end{array}$ & Co-investigator & Acquisition of data \\
\hline Luisa Maria Caniatti & $\begin{array}{l}\text { U.O.di Neurologia - Azienda ospedale universita' S. } \\
\text { Anna di Ferrara - Cona Ferrara }\end{array}$ & Co-investigator & Acquisition of data \\
\hline Paola Crociani & $\begin{array}{l}\text { Centro SM UO Neurologia, Fondazione IRCCS Casa } \\
\text { Sollievo della Sofferenza, San Giovanni Rotondo (FG) }\end{array}$ & Co-investigator & Acquisition of data \\
\hline Luca Massacesi & $\begin{array}{l}\text { Centro di riferimento regionale per il trattamento della } \\
\text { sclerosi multipla, SOD Neurologia II, AOU Careggi, } \\
\text { Dipartimento Neuroscienze - Università di Firenze }\end{array}$ & Co-investigator & Acquisition of data \\
\hline Susanna Malagù & Centro Sclerosi Multipla - U.O. di Neurologia - Ospedale Bufalini & Co-investigator & Acquisition of data \\
\hline Giuseppe Ribizzi & $\begin{array}{l}\text { U.O. Neurologia. Dipartimento Di Neuroscienze E } \\
\text { Organi Di Senso - Ospedale Policlinico San Martino }\end{array}$ & Co-investigator & Acquisition of data \\
\hline Simonetta Venturi & Ambulatorio Sclerosi Multipla - E.O. Ospedale Galliera & Co-investigator & Acquisition of data \\
\hline Paola Gazzola & SC Neurologia - Ospedale P. Antero Micone - ASL 3 Genovese & Co-investigator & Acquisition of data \\
\hline Nicola Renato Pizio & Ambulatorio Sclerosi Multipla - Neurologia ASL 4 Chiavarese & Co-investigator & Acquisition of data \\
\hline Giampaolo Brichetto & Servizio di Riabilitazione AISM Liguria & Co-investigator & Acquisition of data \\
\hline Katrin Plewnia & Centro SM USL Sudest, U.O.C. Neurologia, Osp. Misericordia & Co-investigator & Acquisition of data \\
\hline Paolo Bellantonio & Centro Sclerosi Multipla - IRCCS Neuromed & Co-investigator & Acquisition of data \\
\hline Roberto Balgera & $\begin{array}{l}\text { Centro Sclerosi Multipla - Divisione di Neurologia - Azienda } \\
\text { Ospedaliera A. Manzoni di Lecco }\end{array}$ & Co-investigator & Acquisition of data \\
\hline Francesca De Robertis & Divisione di Neurologia - Ospedale 'Vito Fazzi' & Co-investigator & Acquisition of data \\
\hline Silvia Fermi & U.O Neurologia Ospedale Maggiore di Lodi & Co-investigator & Acquisition of data \\
\hline Franco Fausto & Ambulatorio Sclerosi Multipla - Ospedale della Versilia & Co-investigator & Acquisition of data \\
\hline Monica Mazzoni & $\begin{array}{l}\text { Centro Malattie Disimmuni Del SNC E SNP Ospedale } \\
\text { San Luca Lucca }\end{array}$ & Co-investigator & Acquisition of data \\
\hline Giuseppe Meucci & $\begin{array}{l}\text { Ambulatorio Sclerosi Multipla - Unita' Operativa di } \\
\text { Neurologia e Neurofisiopatologia, Spedali Riuniti di } \\
\text { Livorno } 10 \text { padiglione II piano }\end{array}$ & Co-investigator & Acquisition of data \\
\hline Elisabetta Cartechini & $\begin{array}{l}\text { Centro Sclerosi Multipla - c/o UOC Neurologia - Ospedale } \\
\text { di Macerata }\end{array}$ & Co-investigator & Acquisition of data \\
\hline Guido Cavaletti & $\begin{array}{l}\text { Centro di neuroimmunologia ASST MONZA E } \\
\text { BRIANZA - Ospedale San Gerardo }\end{array}$ & Co-investigator & Acquisition of data \\
\hline Maria Buccafusca & Centro Sclerosi Multipla - A.O.U. Policlinico Martino & Co-investigator & Acquisition of data \\
\hline Placido Bramanti & IRCCS, Centro Neurolesi Bonino Pulejo & Co-investigator & Acquisition of data \\
\hline Marzia Romeo & Centro Sclerosi Multpla - Ospedale San Raffaele & Co-investigator & Acquisition of data \\
\hline Marco Rovaris & Centro SM, IRCCS Fondazione Don Carlo Gnocchi & Co-investigator & Acquisition of data \\
\hline Marco Ronzoni & Centro SM - ASST-Rhodense, Garbagnate Milanese & Co-investigator & Acquisition of data \\
\hline Torri Clerici Valentina & Fondazione IRCCS Istituto Neurologico Carlo Besta & Co-investigator & Acquisition of data \\
\hline Luca Chiveri & $\begin{array}{l}\text { Centro SM - Dipartimento Di Neuroscienze -ASST Ovest } \\
\text { Milanese, Legnano (MI) }\end{array}$ & Co-investigator & Acquisition of data \\
\hline Pierluigi Bertora & $\begin{array}{l}\text { Centro Sclerosi Multipla - UO Neurologia - ASST FBF } \\
\text { SACCO P.O. L. Sacco }\end{array}$ & Co-investigator & Acquisition of data \\
\hline Simone Tonietti & $\begin{array}{l}\text { Centro Sclerosi Multipla Ospedale San Carlo - ASST Santi } \\
\text { Paolo e Carlo }\end{array}$ & Co-investigator & Acquisition of data \\
\hline Milena De Riz & $\begin{array}{l}\text { Centro Sclerosi Multipla- Fondazione IRCCS Ca' Granda } \\
\text { Ospedale Maggiore Policlinico di Milano }\end{array}$ & Co-investigator & Acquisition of data \\
\hline Alessandra Protti & ASST GRANDE OSPEDALE METROPOLITANO NIGUARDA & Co-investigator & Acquisition of data \\
\hline Patrizia Sola & Centro Malattie Demielinizzanti - Dipartimento Di & Co-investigator & Acquisition of data \\
\hline
\end{tabular}

Neuroscienze, Azienda Ospedaliero-Universitaria/OCSAE, UO Neurologia, Universita' Di Modena E Reggio Emilia, Modena

Mario Santangelo

Carlo Maremmani

Gabriella Cacchio'

Rosa Iodice
U.O. C. Di Neurologia - AUSL - Modena, Ospedale Di Carpi

Centro Sclerosi Multipla - Divisione Neurologica - Civico Ospedale di Carrara

Ambulatorio dedicato Sclerosi Multipla, UO Neurologia AV5, Ospedale C. e G. Mazzoni

\section{Co-investigator \\ Co-investigator


Table 4 (continued)

\begin{tabular}{|c|c|c|c|}
\hline Name & Location & Role & Contribution \\
\hline & $\begin{array}{l}\text { UOC Neurologia e Centro per l'Epilessia, Università Federico } \\
\text { II di Napoli }\end{array}$ & & \\
\hline Michele Ragno & $\begin{array}{l}\text { Ambulatorio Sclerosi Multipla - UO di Neurologia } \\
\text { AV5 - Ospedale Civile Madonna del Soccorso- San } \\
\text { Benedetto del Tronto }\end{array}$ & Co-investigator & Acquisition of data \\
\hline Leonardo Sinisi & $\begin{array}{l}\text { Centro SM, UOC Di Neurologia, Ospedale San Paolo, } \\
\text { ASL Napoli } 1 \text { Centro, Napoli }\end{array}$ & Co-investigator & Acquisition of data \\
\hline Vincenzo La Bua & $\begin{array}{l}\text { CENTRO REGIONALE SCLEROSI MULTIPLA .... } \\
\text { ADULTO - OSPEDALE PEDIATRICO 'G. DI CRISTINA' - } \\
\text { ARNAS CIVICO - DI CRISTINA BENFRATELLI - } \\
\text { PALERMO }\end{array}$ & Co-investigator & Acquisition of data \\
\hline Roberto Cantello & $\begin{array}{l}\text { Centro Sclerosi Multipla, Clinica Neurologica, Dipartimento } \\
\text { di Medicina Traslazionale, Università del Piemonte Orientale }\end{array}$ & Co-investigator & Acquisition of data \\
\hline Maria Luisa Piras & $\begin{array}{l}\text { Centro diagnosi, cura e ricerca per Sclerosi Multipla - } \\
\text { Ospedale S. Francesco - USL } 3\end{array}$ & Co-investigator & Acquisition of data \\
\hline Salvatore Cottone & $\begin{array}{l}\text { Centro Di Riferimento Regionale Per La Malattie } \\
\text { Neurologiche a Patogenesi Immunitaria A.O.O.R. Villa } \\
\text { Sofia-Cervello }\end{array}$ & Co-investigator & Acquisition of data \\
\hline Luigi M. E. Grimaldi & Fondazione Istituto G. Giglio - Centro SM, Cefalu’ & Co-investigator & Acquisition of data \\
\hline Francesco Corea & Neurologia Centro SM - Ospedale San Giovanni Battista & Co-investigator & Acquisition of data \\
\hline Giuseppe Santangelo & $\begin{array}{l}\text { CENTRO REGIONALE SCLEROSI MULTIPLA IN ETA' } \\
\text { EVOLUTIVA - OSPEDALE PEDIATRICO } \\
\text { 'G. DI CRISTINA' - ARNAS CIVICO - DI CRISTINA } \\
\text { BENFRATELLI - PALERMO }\end{array}$ & Co-investigator & Acquisition of data \\
\hline Paolo Immovili & Ospedale Guglielmo da Saliceto - UOC Neurologia & Co-investigator & Acquisition of data \\
\hline Paolo Gallo & $\begin{array}{l}\text { Centro Specializzato Regionale per la Sclerosi Multipla } \\
\text { (CeSMuV) - Regione Veneto-Dipartimento Di Neuroscienze } \\
\text { DNS-Azienda Ospedaliera - Universita' degli Studi } \\
\text { Di Padova }\end{array}$ & Co-investigator & Acquisition of data \\
\hline Francesco D'Andrea & $\begin{array}{l}\text { Centro SM - UO Neurologia - Casa Di Cura Villa Serena, } \\
\text { Pescara }\end{array}$ & Co-investigator & Acquisition of data \\
\hline Cristina Frittelli & $\begin{array}{l}\text { Ambulatorioi Malattie Demielinizzanti - UOC Neurologia, } \\
\text { Ospedale Lotti }\end{array}$ & Co-investigator & Acquisition of data \\
\hline Livia Pasquali & $\begin{array}{l}\text { Centro Malattie Demielinizzanti UO Neurologia, Dipartimento } \\
\text { Di Medicina Clinica E Sperimentale, Universita' Di Pisa }\end{array}$ & Co-investigator & Acquisition of data \\
\hline Mario Falcini & $\begin{array}{l}\text { Ospedale di Prato - Centro per la Sclerosi Multipla - Unita' } \\
\text { Operativa di Neurologia }\end{array}$ & Co-investigator & Acquisition of data \\
\hline Franco Granella & $\begin{array}{l}\text { Centro Sclerosi Multipla - Azienda Ospedaliero-Universitaria } \\
\text { di Parma }\end{array}$ & Co-investigator & Acquisition of data \\
\hline Ilaria Pesci & $\begin{array}{l}\text { Centro SM UOC Neurologia Ospedale VAIO di Fidenza (PR), } \\
\text { AUSL PR }\end{array}$ & Co-investigator & Acquisition of data \\
\hline Anna Luisa Ancona & $\begin{array}{l}\text { Ospedale San Jacopo di Pistoia Ambulatorio Malattie } \\
\text { Demielinizzanti - Divisione Neurologica }\end{array}$ & Co-investigator & Acquisition of data \\
\hline Umberto Aguglia & $\begin{array}{l}\text { Ambulatorio Sclerosi Multipla - Grande Ospedale } \\
\text { Metropolitano Bianchi Melacrino Morelli }\end{array}$ & Co-investigator & Acquisition of data \\
\hline Roberto Bergamaschi & $\begin{array}{l}\text { S.S. Sclerosi Multipla dell'IRCCS Fondazione Istituto } \\
\text { Neurologico Nazionale C.Mondino }\end{array}$ & Co-investigator & Acquisition of data \\
\hline Sara Montepietra & $\begin{array}{l}\text { Centro SM, U.O.C. Neurologia, Ospedaliera Santa Maria Nuova, } \\
\text { AUSL Reggio Emilia }\end{array}$ & Co-investigator & Acquisition of data \\
\hline Antonello Giordano & S.C. Provinciale di Neurologia - ASP Ragusa - P.O. R. Guzzardi & Co-investigator & Acquisition of data \\
\hline Mario Di Napoli & $\begin{array}{l}\text { Centro Sclerosi Multipla - U.O. di Neurologia - Ospedale San } \\
\text { Camillo De Lellis }\end{array}$ & Co-investigator & Acquisition of data \\
\hline Silvia Romano & $\begin{array}{l}\text { CENTERS Centro Neurologico Terapie Sperimentali - Sapienza } \\
\text { Universita' Di Roma, Azienda Ospedaliera S. Andrea }\end{array}$ & Co-investigator & Acquisition of data \\
\hline Massimiliano Mirabella & $\begin{array}{l}\text { UO Sclerosi Multipla, Fondazione Policlinico } \\
\text { Universitario A. Gemelli IRCCS, Universita' Cattolica } \\
\text { Del Sacro Cuore }\end{array}$ & Co-investigator & Acquisition of data \\
\hline Antonella Conte & $\begin{array}{l}\text { Centro Clinico Policlinico Umberto I -Universita' } \\
\text { di Roma Sapienza }\end{array}$ & Co-investigator & Acquisition of data \\
\hline Marco Peresson & Centro Clinico Sclerosi Multipla Ospedale & Co-investigator & Acquisition of data \\
\hline
\end{tabular}


Table 4 (continued)

\begin{tabular}{|c|c|}
\hline Name & Location \\
\hline Maria Grazia Grasso & Centro SM - Fondazione S. Lucia \\
\hline Elisabetta Ferraro & Centro SM - PO San Filippo Neri - ASL Roma 1, Roma \\
\hline Fioravante Capone & $\begin{array}{l}\text { Centro SM - UOC Di Neurologia - Policlinico } \\
\text { Universitario Campus Bio-Medico Di Roma }\end{array}$ \\
\hline Girolama Alessandra Marfia & $\begin{array}{l}\text { UOSD Sclerosi Multipla, Policlinico Universitario } \\
\text { Tor Vergata, Roma }\end{array}$ \\
\hline Daniela de Pascalis & $\begin{array}{l}\text { Centro regionale per la diagnosi e cura della Sclerosi } \\
\text { Multipla e malattie demielinizzanti, Osp. S. Eugenio } \\
\text { di Roma }\end{array}$ \\
\hline Carlo Piantadosi & $\begin{array}{l}\text { Centro Sclerosi Multipla - Az. Ospedaliera S. } \\
\text { Giovanni - Addolorata }\end{array}$ \\
\hline Massimiliano Valeriani & $\begin{array}{l}\text { Centro per la diagnosi e la cura delle malattie } \\
\text { infiammatorie demielinizzanti in eta' } \\
\text { pediatrica - Ospedale Bambino Gesu' }\end{array}$ \\
\hline Vincenzo Busillo & $\begin{array}{l}\text { U.O. di Neurologia- Ospedale Maria SS. } \\
\text { Addolorata - Centro Diagnosi e Terapia Sclerosi } \\
\text { Multipla }\end{array}$ \\
\hline Paolo Barone & $\begin{array}{l}\text { Divisione Neurologica - Azienda Ospedaliera San } \\
\text { Giovanni di Dio }\end{array}$ \\
\hline Monica Ulivelli & $\begin{array}{l}\text { UOS Neuroimmunologia clinica- Ambulatorio Sclerosi } \\
\text { multipla-AOUS }\end{array}$ \\
\hline Nicola De Stefano & $\begin{array}{l}\text { Ambulatorio Sclerosi multipla - U.O.S.A. Malattie } \\
\text { Neurodegenerative e Demielinizzanti - Azienda } \\
\text { Ospedaliera Universitaria Senese }\end{array}$ \\
\hline Monica Ulivelli & $\begin{array}{l}\text { UOC Neurologia e Neurofisiologia Clinica - Universita' } \\
\text { degli Studi di Siena }\end{array}$ \\
\hline Giuseppe Santuccio & $\begin{array}{l}\text { Azienza Socio Sanitaria Territoriale (ASST) della } \\
\text { Valtellina e Alto Lario - Sedi di Sondrio e } \\
\text { Sondalo - Reparto di Neurologia }\end{array}$ \\
\hline Sergio Parodi & $\begin{array}{l}\text { Centro Sclerosi Multipla e Malattie Demielinizzanti - } \\
\text { Ospedale Civile S. Andrea - USL } 5\end{array}$ \\
\hline Sebastiano Bucello & Ospedale Muscatello di Augusta \\
\hline Sebastiano Traccis & $\begin{array}{l}\text { Centro Prescrittore Sclerosi Multipla - U.O. di } \\
\text { Neurologia - Presidio Ospedaliero di Ozieri - ASL } \\
\text { N. } 1 \text { Sassari }\end{array}$ \\
\hline Roberto Zarbo & $\begin{array}{l}\text { Centro Per La Diagnosi E Cura Della SM - Azienda } \\
\text { Ospedaliero-Universitaria Di Sassari, Sassari }\end{array}$ \\
\hline Tiziana Tassinari & $\begin{array}{l}\text { Centro SM Pietra Ligure S.C. Neurologia - Ospedale } \\
\text { Santa Corona }\end{array}$ \\
\hline Fabio Bandini & $\begin{array}{l}\text { Centro Sclerosi Multipla, Divisione di Neurologia, } \\
\text { Ospedale S. Paolo }\end{array}$ \\
\hline Annamaria Marson & ASLTO4 - Neurologia - Ospedale Chivasso \\
\hline Paola Cavalla & $\begin{array}{l}\text { Centro SM - Neurologia } 1 \text { D.U. - AOU Citta' Della } \\
\text { Salute E Della Scienza Di Torino }\end{array}$ \\
\hline Marinella Clerico & $\begin{array}{l}\text { S.C.D.U. di Neurologia } 1 \text { - Azienda Ospedaliero } \\
\text { Universitaria San Luigi Gonzaga }\end{array}$ \\
\hline Giulia De Rosa & $\begin{array}{l}\text { Centro Sclerosi Multipla - Divisione Di Neurologia, } \\
\text { Ospedale Civile, ASL } 4\end{array}$ \\
\hline Antonio Bertolotto & $\begin{array}{l}\text { Centro Di Riferimento Regionale Per La SM } \\
\text { (CRESM) - SCDO Neurologia - AOU San Luigi, } \\
\text { Orbassano }\end{array}$ \\
\hline Daniele Imperiale & $\begin{array}{l}\text { Centro Sclerosi Multipla - Divisione di } \\
\text { Neurologia - Ospedale Maria Vittoria }\end{array}$ \\
\hline Paola Sarchielli & $\begin{array}{l}\text { Centro Malattie Demielinizzanti - Ospedale } \\
\text { S. Maria della Misericordia }\end{array}$ \\
\hline Maria Grazia Celani & $\begin{array}{l}\text { Servizio Per Le Malattie Demielinizzanti - SC Di } \\
\quad \text { Neurofisiopatologia-Azienda Ospedaliera Di Perugia }\end{array}$ \\
\hline Bruno Marini & $\begin{array}{l}\text { U.O.C. Neurologia,ULSS2- Marca Trevigiana-Regione } \\
\text { Veneto - Ospedale S. Giacomo Apostolo, } \\
\text { Castelfranco Veneto }\end{array}$ \\
\hline
\end{tabular}

Role

Contribution

Co-investigato

Acquisition of data

Co-investigator

Co-investigator

Acquisition of data

Co-investigator

Acquisition of data

Co-investigator

Acquisition of data

entro regionale per la diagnosi e cura della Sclerosi

Multipla e malattie demielinizzanti, Osp. S. Eugenio

entro Sclerosi Multipla - Az. Ospedaliera S.

Giovanni - Addolorata

Addolorata - Centro Diagnosi e Terapia Sclerosi

Giovanni di Dio

OS Neuroimmunologia clinica- Ambulatorio Sclerosi

degli Studi di Siena

zienza Socio Sanitaria Territoriale (ASST) del

Ospedale Civile S. Andrea - USL

Ospedale Muscatello di Augusta

urologia - Presidio Osped

Ospedaliero-Universitaria Di Sassari, Sassari

Santa Corona

entro Sclerosi Multipla, Divisione di Neurologia,

Centro SM - Neurologia 1 D.U. - AOU Citta' Della

Universitaria San Luigi Gonzaga

entro Sclerosi Multipla - Divisione Di Neurologia,

Ospedale Civile, ASL Orbassano

entro Malattie Demielinizzanti - Ospedale

Co-investigator

Acquisition of data

Co-investigator

Acquisition of data

Co-investigator

Acquisition of data

Co-investigator

Acquisition of data

Co-investigator

Acquisition of data

Co-investigator

Acquisition of data

Co-investigator

Acquisition of data

Co-investigator

Acquisition of data

Co-investigator

Acquisition of data

Co-investigator

Acquisition of data

Co-investigator

Acquisition of data

Co-investigator

Acquisition of data

Co-investigator

Acquisition of data

Co-investigator

Acquisition of data

Co-investigator

Acquisition of data

Co-investigator

Acquisition of data

Co-investigator

Acquisition of data

Co-investigator

Acquisition of data

Co-investigator

Acquisition of data

Co-investigator

Acquisition of data

Co-investigator

Acquisition of data

Co-investigator

Acquisition of data

Co-investigator

Acquisition of data

Co-investigator Acquisition of data 
Table 4 (continued)

\begin{tabular}{|c|c|c|c|}
\hline Name & Location & Role & Contribution \\
\hline & $\begin{array}{l}\text { Ambulatorio Malattie Demielinizzanti - Unita' } \\
\text { Operativa Complessa di Neurologia - Ospedale } \\
\text { Civile di Conegliano Veneto }\end{array}$ & & \\
\hline Mauro Zaffaroni & $\begin{array}{l}\text { Centro Sclerosi Multipla, ASST Della Valle Olona, } \\
\text { Ospedale Di Gallarate }\end{array}$ & Co-investigator & Acquisition of data \\
\hline Davide Nasuelli & $\begin{array}{l}\text { ASST Della Valle Olona Presidio Ospedaliero Di } \\
\text { Saronno Ambulatorio Sclerosi Multipla U }\end{array}$ & Co-investigator & Acquisition of data \\
\hline Paola Banfi & $\begin{array}{l}\text { Centro Sclerosi Multipla, Ambulatorio Malattie } \\
\text { Demielinizzanti - Ospedale di Circolo e } \\
\text { Fondazione Macchi }\end{array}$ & Co-investigator & Acquisition of data \\
\hline Andrea Mauro Brioschi & $\begin{array}{l}\text { Istituto Auxologico Italiano IRCCS - Istituto } \\
\text { Scientifico Ospedale S. Giuseppe e Ambulatorio }\end{array}$ & Co-investigator & Acquisition of data \\
\hline Claudio Solaro & $\begin{array}{l}\text { Dipartimento di Riabilitazione, CRRF "Mons. Luigi } \\
\text { Novarese" }\end{array}$ & Co-investigator & Acquisition of data \\
\hline Rocco Quatrale & $\begin{array}{l}\text { Ambulatorio Sclerosi Multipla - Divisione di } \\
\text { Neurologia - Ospedale dell'Angelo }\end{array}$ & Co-investigator & Acquisition of data \\
\hline Patrizia Rossi & $\begin{array}{l}\text { Ambulatorio Sclerosi Multipla e Malattie } \\
\text { Demielinizzanti del SNC - UOC di } \\
\text { Neurologia - Ospedale San Bassiano }\end{array}$ & Co-investigator & Acquisition of data \\
\hline Alberto Gajofatto & $\begin{array}{l}\text { Policlinico G.B. Rossi - Clinica Neurologica, } \\
\text { Dipartimento di Neuroscienze, Biomedicina } \\
\text { e Movimento }\end{array}$ & Co-investigator & Acquisition of data \\
\hline Paolo Giannetti & Centro Sclerosi Mulpltipla - Ospedale Belcolle & Co-investigator & Acquisition of data \\
\hline Vincenzo La Bua & $\begin{array}{l}\text { Centro Sclerosi Multipla - Ospedale ARNAS } \\
\text { Civico di Cristina Benfratelli }\end{array}$ & Co-investigator & Acquisition of data \\
\hline Pierangelo Veggiotti & $\begin{array}{l}\text { Centro Sclerosi Multipla Pediatrica - UOC } \\
\text { Neurologia Pediatrica Ospedale V Buzzi, } \\
\text { ASST Fatebenefratelli Sacco }\end{array}$ & Co-investigator & Acquisition of data \\
\hline
\end{tabular}

Open Access This article is licensed under a Creative Commons Attribution 4.0 International License, which permits use, sharing, adaptation, distribution and reproduction in any medium or format, as long as you give appropriate credit to the original author(s) and the source, provide a link to the Creative Commons licence, and indicate if changes were made. The images or other third party material in this article are included in the article's Creative Commons licence, unless indicated otherwise in a credit line to the material. If material is not included in the article's Creative Commons licence and your intended use is not permitted by statutory regulation or exceeds the permitted use, you will need to obtain permission directly from the copyright holder. To view a copy of this licence, visit http://creativecommons.org/licenses/by/4.0/.

\section{References}

1. Reich DS, Lucchinetti CF, Calabresi PA. Multiple Sclerosis. The New England journal of medicine. 2018;378(2):169-80.

2. Aubagio (teriflunomide) tablets hp, sanofi.eu/aubagio (accessed April.

3. Tecfidera (dimethyl fumarate) hw, ema.europa.eu/docs/it_IT/ document_library/,EPAR_-_Product_Information/human/ 002601/,WC500162069.pdf (accessed April.

4. Confavreux C, O'Connor P, Comi G, Freedman MS, Miller AE, Olsson TP, et al. Oral teriflunomide for patients with relapsing multiple sclerosis (TOWER): a randomised, double-blind, placebo-controlled, phase 3 trial. The Lancet Neurology. 2014;13(3):247-56.

5. Gold R, Kappos L, Arnold DL, Bar-Or A, Giovannoni G, Selmaj K, et al. Placebo-Controlled Phase 3 Study of Oral BG-12 for Relapsing Multiple Sclerosis. New England Journal of Medicine. 2012;367(12):1098-107.

6. O'Connor P, Comi G, Freedman MS, Miller AE, Kappos L, Bouchard JP, et al. Long-term safety and efficacy of teriflunomide: Nine-year follow-up of the randomized TEMSO study. Neurology. 2016;86(10):920-30.

7. Arnold DL, Gold R, Kappos L, Bar-Or A, Giovannoni G, Selmaj K, et al. Effects of delayed-release dimethyl fumarate on MRI measures in the Phase 3 DEFINE study. Journal of neurology. 2014;261(9):1794-802.

8. Cramer JA, Roy A, Burrell A, Fairchild CJ, Fuldeore MJ, Ollendorf DA, et al. Medication compliance and persistence: terminology and definitions. Value in health : the journal of the International Society for Pharmacoeconomics and Outcomes Research. 2008;11(1):44 7.

9. Ivanova JI, Bergman RE, Birnbaum HG, Phillips AL, Stewart M, Meletiche DM. Impact of medication adherence to diseasemodifying drugs on severe relapse, and direct and indirect costs among employees with multiple sclerosis in the US. Journal of medical economics. 2012;15(3):601-9.

10. Zettl UK, Schreiber H, Bauer-Steinhusen U, Glaser T, Hechenbichler K, Hecker M. Baseline predictors of persistence to first disease-modifying treatment in multiple sclerosis. Acta neurologica Scandinavica. 2017;136(2):116-21. 
11. D'Amico E, Patti F, Zanghì A, Zappia M. A Personalized Approach in Progressive Multiple Sclerosis: The Current Status of Disease Modifying Therapies (DMTs) and Future Perspectives. Int J Mol Sci. 2016;17(10):1725. https://doi.org/10.3390/ijms 17101725.

12. D'Amico E, Zanghì A, Callari G, Borriello G, Gallo A, Graziano G, et al. Comparable efficacy and safety of dimethyl fumarate and teriflunomide treatment in Relapsing-Remitting Multiple Sclerosis: an Italian real-word multicenter experience. Ther Adv Neurol Disord. 2018;11:1756286418796404-.

13. D'Amico E, Zanghi A, Sciandra M, Borriello G, Callari G, Gallo A, et al. Discontinuation of teriflunomide and dimethyl fumarate in a large Italian multicentre population: a 24-month real-world experience. Journal of neurology. 2019;266(2):411-6.

14. Auricchio F, Scavone C, Cimmaruta D, Di Mauro G, Capuano A, Sportiello L, et al. Drugs approved for the treatment of multiple sclerosis: review of their safety profile. Expert opinion on drug safety. 2017;16(12):1359-71.

15. Filippini G, Del Giovane C, Vacchi L, D’Amico R, Di Pietrantonj $\mathrm{C}$, Beecher D, et al. Immunomodulators and immunosuppressants for multiple sclerosis: a network meta-analysis. The Cochrane database of systematic reviews. 2013(6):Cd008933.

16. Johnson KM, Zhou H, Lin F, Ko JJ, Herrera V. Real-World Adherence and Persistence to Oral Disease-Modifying Therapies in Multiple Sclerosis Patients Over 1 Year. Journal of Managed Care \& Specialty Pharmacy. 2017;23(8):844-52.

17. Burks J, Marshall TS, Ye X. Adherence to disease-modifying therapies and its impact on relapse, health resource utilization, and costs among patients with multiple sclerosis. Clinicoecon Outcomes Res. 2017;9:251-60.

18. D'Amico E, Zanghì A, Sciandra M, Lanzillo R, Callari G, Cortese A et al. Dimethyl fumarate vs Teriflunomide: an Italian time-toevent data analysis. J Neurol. 2020;267(10):3008-20. https://doi. org/10.1007/s00415-020-09959-1.

19. Trojano M, Bergamaschi R, Amato MP, Comi G, Ghezzi A, Lepore $\mathrm{V}$, et al. The Italian multiple sclerosis register. Neurological sciences : official journal of the Italian Neurological Society and of the Italian Society of Clinical Neurophysiology. 2019;40(1):15565.

20. D'Amico E, Leone C, Caserta C, Patti F. Oral drugs in multiple sclerosis therapy: an overview and a critical appraisal. Expert review of neurotherapeutics. 2015;15(7):803-24.

21. Polman CH, Reingold SC, Banwell B, Clanet M, Cohen JA, Filippi M, Fujihara K, Havrdova E, Hutchinson M, Kappos L, Lublin FD, Montalban X, O'Connor P, Sandberg-Wollheim M, Thompson AJ, Waubant E, Weinshenker B, Wolinsky JS. Diagnostic criteria for multiple sclerosis: 2010 revisions to the McDonald criteria. Ann Neurol. 2011;69(2):292-302.

22. https://www.ema.europa.eu/en/documents/product-information/ rebif-epar-product-information_en.pdf. Accessed July 2020.

23. https://www.ema.europa.eu/en/documents/psusa/glatiramer-listnationally-authorised-medicinal-products-psusa/00001529/ 201711_en.pdf. Accessed July 2020.

24. https://www.ema.europa.eu/en/medicines/human/EPAR/betaferon. Accessed July 2020.

25. https://www.emdserono.com/us-en/pi/rebif-pi.pdf). Accessed July 2020.
26. VanderWeele TJ, Ding P. Sensitivity Analysis in Observational Research: Introducing the E-Value. Annals of internal medicine. 2017;167(4):268-74.

27. Carpenter JR, Kenward MG, White IR. Sensitivity analysis after multiple imputation under missing at random: a weighting approach. Statistical methods in medical research. 2007;16(3):25975.

28. Ferro MA. Missing data in longitudinal studies: cross-sectional multiple imputation provides similar estimates to full-information maximum likelihood. Annals of epidemiology. 2014;24(1):75-7.

29. Héraud-Bousquet V, Larsen C, Carpenter J, Desenclos J-C, Le Strat Y. Practical considerations for sensitivity analysis after multiple imputation applied to epidemiological studies with incomplete data. BMC Medical Research Methodology. 2012;12(1):73.

30. Papadopoulos D, Mitsikostas DD. Oral Disease-Modifying Treatments for Relapsing Multiple Sclerosis: A Likelihood to Achieve No Evidence of Disease Activity or Harm Analysis. CNS drugs. 2018;32(11):1069-78.

31. Amato MP, Portaccio E, Ghezzi A, Hakiki B, Zipoli V, Martinelli $\mathrm{V}$, et al. Pregnancy and fetal outcomes after interferon-beta exposure in multiple sclerosis. Neurology. 2010;75(20):1794-802.

32. Ghezzi A, Amato MP, Makhani N, Shreiner T, Gartner J, Tenembaum S. Pediatric multiple sclerosis: Conventional firstline treatment and general management. Neurology. 2016;87(9 Suppl 2):S97-s102.

33. Miller AE, Rhoades RW. Treatment of relapsing-remitting multiple sclerosis: current approaches and unmet needs. Current opinion in neurology. 2012;25 Suppl:S4-10.

34. Vermersch P, Czlonkowska A, Grimaldi LM, Confavreux C, Comi G, Kappos L, et al. Teriflunomide versus subcutaneous interferon beta-1a in patients with relapsing multiple sclerosis: a randomised, controlled phase 3 trial. Multiple sclerosis (Houndmills, Basingstoke, England). 2014;20(6):705-16.

35. Trojano M, Tintore M, Montalban X, Hillert J, Kalincik T, Iaffaldano $\mathrm{P}$, et al. Treatment decisions in multiple sclerosis - insights from real-world observational studies. Nature reviews Neurology. 2017;13(2):105-18.

36. Rosenbaum PR, Rubin DR, The central role of the propensity score in observational studies for causal effects. Biometrika. 1983;70(1): 41-55. https://doi.org/10.1093/biomet/70.1.41.

37. Austin PC, Grootendorst P, Anderson GM. A comparison of the ability of different propensity score models to balance measured variables between treated and untreated subjects: a Monte Carlo study. Statistics in medicine. 2007;26(4):734-53.

38. Bergstra SA, Sepriano A, Ramiro S, Landewe R. Three handy tips and a practical guide to improve your propensity score models. RMD open. 2019;5(1):e000953.

39. Kalincik T, Butzkueven H. Observational data: Understanding the real MS world. Multiple sclerosis (Houndmills, Basingstoke, England). 2016;22(13):1642-8.

40. Mayssam EN, Eid C, Khoury SJ, Hannoun S. No evidence of disease activity: Is it an aspirational therapeutic goal in multiple sclerosis? Multiple sclerosis and related disorders. 2020;40:101935.

Publisher's Note Springer Nature remains neutral with regard to jurisdictional claims in published maps and institutional affiliations. 